\title{
THE EFFECTS OF POSSIBLE CONTAMINATION ON THE RADIOCARBON DATING OF THE DEAD SEA SCROLLS II: EMPIRICAL METHODS TO REMOVE CASTOR OIL AND SUGGESTIONS FOR REDATING
}

\author{
Kaare Lund Rasmussen ${ }^{1,2} \bullet$ Johannes van der Plicht ${ }^{3} \bullet$ Gregory Doudna ${ }^{4} \bullet$ Frederik Nielsen $^{1} \bullet$ \\ Peter Højrup ${ }^{5}$ Erling Halfdan Stenby ${ }^{6}$ Carl Th Pedersen $^{1}$
}

\begin{abstract}
While kept at the Rockefeller Museum in East Jerusalem, many Dead Sea Scroll fragments were exposed to castor oil by the original team of editors in the course of cleaning the parchments. Castor oil must be regarded as a serious contaminant in relation to radiocarbon dating. If modern castor oil is present and is not removed prior to dating, the ${ }^{14} \mathrm{C}$ dates will be skewed artificially towards modern values. In Rasmussen et al. (2001), it was shown that the standard AAA pretreatment procedure used in the 2 previous studies dating Dead Sea Scroll samples (Bonani et al. 1992; Jull et al. 1995) is not capable of removing castor oil from parchment samples. In the present work, we show that it is unlikely that castor oil reacts with the amino acids of the parchment proteins, a finding which leaves open the possibility of devising a cleaning method that can effectively remove castor oil. We then present 3 different pretreatment protocols designed to effectively remove castor oil from parchment samples. These involve 3 different cleaning techniques: extraction with supercritical $\mathrm{CO}_{2}$, ultrasound cleaning, and Soxhlet extraction-each with their own advantages and disadvantages. Our data show that the protocol involving Soxhlet extraction is the best suited for the purpose of decontaminating the Dead Sea Scrolls, and we recommend that this protocol be used in further attempts to ${ }^{14} \mathrm{C}$ date the Dead Sea Scrolls. If such an attempt is decided on by the proper authorities, we propose a list of Scroll texts, which we suggest be redated in order to validate the ${ }^{14} \mathrm{C}$ dates done earlier by Bonani et al. (1992) and Jull et al. (1995).
\end{abstract}

\section{INTRODUCTION}

In 1947-1955, fragments representing approximately 1000 ancient Jewish texts written in Hebrew, Aramaic, and Greek were found in caves at and around Qumran and other sites on the western side of the Dead Sea in the Judean Desert east of Jerusalem. Excavations during 1951-1955 showed that the site of Qumran was destroyed during the Roman invasion at the time of the First Jewish Revolt, AD 66-70. Based on pottery, archaeologists associated the scrolls in the caves with habitation at Qumran preceding this destruction. As early as 1950, Willard Libby's second sample to demonstrate that the new method of radiocarbon dating worked was a linen item associated with one of the Dead Sea Scrolls. However, it was not feasible to date scrolls directly using this new method at that time because it required the destruction of large amounts of sample material. With the advent of accelerator mass spectrometry (AMS) to obtain ${ }^{14} \mathrm{C}$ dates in the late 1970s, it became possible to date samples cut from the margins of individual texts written on animal skin and papyrus. Two series of ${ }^{14} \mathrm{C}$ dates on Dead Sea Scrolls were measured at Zurich (Bonani et al. 1992) and at Tucson (Jull et al. 1995). These 2 series comprise 31 different Dead Sea texts, 19 of which were from caves in the vicinity of Qumran.

Later analysis of the data from Zurich and Tucson raised questions concerning possible effects of castor oil and British Museum Leather Dressing on these ${ }^{14} \mathrm{C}$ dates (Doudna 1998; Rasmussen et al. 2001). Both substances contain modern carbon, and both were applied to Dead Sea Scrolls worked on during the 1950s at the Rockefeller Museum in East Jerusalem (which included most of the Dead

\footnotetext{
${ }^{1}$ Institute of Physics and Chemistry, University of Southern Denmark, Campusvej 55, DK-5230 Odense M, Denmark. ${ }^{2}$ Corresponding author. Email: klr@ifk.sdu.dk.

${ }^{3}$ Centrum voor Isotopen Onderzoek, Nijenborgh 4, 9747 AG Groningen, the Netherlands. Also: Faculty of Archaeology, Leiden University, P.O. Box 9515, 2300 RA Leiden, the Netherlands.

${ }^{4}$ Columbia College, 13910 45th Avenue NE \#802, Marysville, Washington 98271, USA.

${ }^{5}$ Institute of Biochemistry and Molecular Biology, University of Southern Denmark, Campusvej 55, DK-5230 Odense M, Denmark.

${ }^{6}$ Dept. of Chemical and Biochemical Engineering, Technical University of Denmark, DK-2800 Kgs. Lyngby, Denmark.
} 
Sea Scrolls). Doudna (1998) pointed out that: (a) the original editors working on the scrolls in the 1950s such as Frank Cross Jr, John Strugnell, and John Allegro had each reported application of castor oil by themselves and their colleagues on the scrolls for cleaning the fragments and for making faint inked letters become more visible to the eye; (b) the standard pretreatment used for the AMS datings probably did not remove castor oil effectively; if present, this would have resulted in ${ }^{14} \mathrm{C}$ dates that would be too young; and (c) any such contamination by castor oil would be invisible under a microscope, and no additional analysis that would detect such contamination was done. The castor oil issue raised questions concerning whether contamination might have affected some dates, in particular some that appeared unusual.

Rasmussen et al. (2001) obtained new insight concerning the castor oil question. First, Rasmussen et al. (2001) concluded from experiments that the standard AAA (acid-alkaline-acid) pretreatment used in the Zurich and Tucson laboratories to prepare the samples for dating is not effective for removing castor oil from medieval parchments. Two coauthors of the Rasmussen et al. (2001) paper, Frank Cross Jr and John Strugnell, warned from their firsthand experience as editors working with the Scrolls in the Rockefeller Museum in the 1950s that the concerns over possible castor oil contamination of these texts were serious and non-trivial. Rasmussen et al. (2001) concluded that if there had been castor oil contamination in any of the parchment samples dated, the AAA pretreatment would not have removed it and the reported ${ }^{14} \mathrm{C}$ date would be younger than the true date of the text due to the admixture of modern carbon from the castor oil with the ancient carbon of the parchment. Rasmussen et al. (2001) also made a quantitative estimate of the amount of error that castor oil contamination of an individual Dead Sea text sample would produce after cleaning with the standard AAA pretreatment: it would be too young by a maximum of about $300{ }^{14} \mathrm{C}$ yr for a sample fully saturated in castor oil. Carmi (2002) commented on our study, criticizing our analysis on 4 grounds. This critique, however, was rebutted by our reply (Rasmussen et al. 2003).

As the next step, a series of tests were undertaken by the present team attempting to find a pretreatment protocol that would ensure removal of castor oil from Dead Sea Scroll samples, if any were present. The practical problem was not in finding a pretreatment procedure that could take out castor oil-several protocols can do this. But many of these pretreatment procedures would destroy the fragile sample desired to be dated as well. So we sought to find a pretreatment protocol that will both remove castor oil and not also destroy all or most of the Dead Sea Scroll parchment sample as well.

Here, we compare 3 different extraction methods, each with their own advantages and disadvantages. For the first time, we report a solution to the problem of decontaminating Dead Sea Scroll parchment samples from castor oil. This justifies a rechecking of the dates obtained during the 1990s, in order to obtain the best possible dates for the Dead Sea Scrolls by the ${ }^{14} \mathrm{C}$ method.

\section{EXPERIMENTAL PROCEDURES}

\section{On the Composition of Castor Oil}

Castor oil is a vegetable oil obtained from the seeds of the castor plant, Ricinus communis. Castor oil (CAS number 8001-79-4) is a colorless to very pale yellow liquid with mild or no odor or taste frequently used for medicinal purposes. Commercial castor oil contains triglycerides consisting of permutations of 8 fatty acids. The approximate amounts are listed in Figure 1 along with the structure of the molecules (Ullmann 2007; A Bech, personal communication, 2008). The double bonds are very reactive and may lead to the formation of free radicals, which in turn can lead to polymerization. Ricinoleic acid is important because of its high abundance, while linoleic acid, despite its much lower abundance, could also be important because its 2 closely spaced double bonds are more 
reactive. Besides the possibility of the formation of polymers, it is conceivable that the formation of free radicals could lead to a reaction with the amino acids of the proteins of the parchment. If this did indeed take place, modern carbon atoms originating from the modern fatty acids would be fixated on the ancient parchment, and thus constitute a very serious obstacle to any attempt at decontaminating samples of castor oil polluted parchment prior to ${ }^{14} \mathrm{C}$ dating.

\begin{tabular}{|c|c|c|c|c|}
\hline Fatty acid & Systematic name & Structure & $\begin{array}{l}\text { Danisco } \\
\text { analyse }\end{array}$ & $\begin{array}{c}\text { Ullman's } \\
\text { lit. }\end{array}$ \\
\hline Ricinoleic acid & $\begin{array}{l}\text { 12-hydroxyoctadec-9- } \\
\text { enoic acid }\end{array}$ & & $88.6 \%$ & $87-91 \%$ \\
\hline Linoleic acid & $\begin{array}{c}\text { Octadeca-9,12-dienoic } \\
\text { acid }\end{array}$ & & $4.1 \%$ & $4-5 \%$ \\
\hline Oleic acid & Octadec-9-enoic acid & & $3.2 \%$ & $4-5 \%$ \\
\hline Palmitic acid & Hexadecanoic acid & & $1.1 \%$ & $2 \%$ \\
\hline Stearic acid & Octadecanoic acid & & $1.2 \%$ & $2 \%$ \\
\hline $\begin{array}{l}\text { Dihydroxystearic } \\
\text { acid }\end{array}$ & & $\begin{array}{l}\text { Depends on position of the two } \\
\text { hydroxyl groups. }\end{array}$ & N/A & $1 \%$ \\
\hline & Nonadecanoic acid & & $0.4 \%$ & N/A \\
\hline Icosanoic acid & & & $0.4 \%$ & N/A \\
\hline Unknown & & N/A & $1.0 \%$ & N/A \\
\hline
\end{tabular}

Figure 1 The fatty acid composition of commercial castor oil. Analyses by Bech (2004) and Ullmann (2007). N/A: value does not apply.

\section{Artificial Aging of Parchment Samples}

In connection with the following experiments, we have in several instances performed artificial aging of the parchment samples after contamination and prior to cleaning. The aim of artificial aging is in the most realistic way possible to simulate chemically what has taken place inside the parchments through a part of their existence. In this study of the Dead Sea Scrolls, we refer to the time span starting from when some of them were treated with castor oil $~ 50 \mathrm{yr}$ ago until now. The parchments have for 20 centuries been situated in an exceptionally dry climate in the desert with a cycling temperature from summer to winter and occasional very high summer temperatures most likely peaking within a few days. During their stay in the Rockefeller Museum, the Scrolls have for $\sim 50 \mathrm{yr}$ 
experienced more or less the same conditions as in the desert, perhaps with a slightly lower temperature and slightly higher humidity. Consequently, the parchments themselves are probably not affected very much during the last $50 \mathrm{yr}$, but the castor oil may be. The castor oil is prone to polymerize or to undergo chemical reactions. As we do not know precisely which reactions have occurred, we cannot determine whether the reactions took place in a short time after exposure, or if they happened progressively over the years, most likely taking place during the times of peaking summer temperatures.

In order to simulate the effects of this age span of $50 \mathrm{yr}$, we have used artificial aging with an elevated temperature for a much shorter time interval. As we do not know precisely which chemical reactions have taken place, we cannot estimate their activation energies and therefore cannot calculate a correct relationship between temperature and time from the Arrhenius equation. Instead, we have made an arbitrary artificial aging consisting of raising the temperature to $60{ }^{\circ} \mathrm{C}$ for 14 days. With this artificial aging we do not claim to match the conditions experienced by the Dead Sea Scrolls in Jerusalem for the last $50 \mathrm{yr}$, but we believe this step is better and more realistic than not doing any artificial aging at all.

\section{Amino Acid Analysis of Parchment Samples}

In order to determine if castor oil has indeed reacted with the amino acids of the proteins of the parchment, we have performed the following experiment. A sample of modern parchment was cut into 2 parts. One part was left uncontaminated, whereas the other was saturated with castor oil. Both samples were artificially aged at $60{ }^{\circ} \mathrm{C}$ for 14 days at $0 \%$ relative humidity in order to assure that any reaction possible indeed did take place. At the University of Southern Denmark, about $0.7 \mathrm{mg}$ of each sample was fully hydrolyzed in $6 \mathrm{M} \mathrm{HCl}, 0.1 \%$ phenol, $0.1 \%$ thioglycolic acid, and the amount of each amino acid was determined by ion exchange chromatography followed by derivatization with ninhydrin, and detection at 440 and $570 \mathrm{~nm}$. Measurements were carried out on a Biochrom-30 amino acid analyzer with a measurement error of about $3 \%$ relative abundance. Two amino acids, trytophan and cysteine, could not be analyzed because they were destroyed in the acid solution. Furthermore, asparagine and glutamine deamidate to the corresponding acids: aspartic acid and glutamic acid. The results are listed in Table 1 and shown in Figure 2. As can be seen, the differences are minute.

The rationale for this experiment is that a reaction between one of the fatty acids in the castor oil and any one of the amino acids present in the parchment would result in a relative decrease of the abundance of that particular amino acid in the castor oil-contaminated sample relative to the untreated sample, i.e. yield a large negative number in the last column of Table 1. The relatively large increases in tyrosine (Tyr) and phenylalanine (Phe) are most likely caused by their low concentration, and not due to actual changes. In any event, the abundances of both are lower in the untreated sample than in the castor oil-treated sample, which precludes the possibility of a reaction between castor oil and parchment. The only amino acid that shows any signs of a decrease in the castor oil treated sample is threonine (Thr), which is $3 \%$ lower in the contaminated sample (see Table 1 and Figure 2). However, 3\% is within the expected uncertainty range, so this decrease is not significant. In Figure 2, we do not see any decreases in abundance that can be interpreted as a result from a reaction between the castor oil and the proteins of the parchment.

These findings indicate that the probable reaction scheme of the castor oil is one of dimerization or polymerization, and not a reaction with the parchment material. Although polymerization can be complex, it leaves open the possibility of designing a cleaning protocol that is capable of removing the castor oil from the parchment. 
Table 1 Abundances of the amino acids in 2 samples of modern parchment. One sample was untreated, the other saturated with castor oil. Both samples were artificially aged by heating to $60{ }^{\circ} \mathrm{C}$ for $2 \mathrm{hr}$ at $0 \%$ relative humidity. Each sample was measured 3 times. The last 2 columns list the difference between the averages and this difference expressed as percent deviation relative to the castor oil-treated sample, respectively.

\begin{tabular}{|c|c|c|c|c|c|c|c|c|c|c|}
\hline \multirow[b]{2}{*}{$\begin{array}{l}\text { Amino } \\
\text { acid }\end{array}$} & \multicolumn{4}{|c|}{ No castor oil } & \multicolumn{4}{|c|}{ Castor oil contaminated } & \multirow[b]{2}{*}{ Diff. } & \multirow[b]{2}{*}{$\%$ Diff. } \\
\hline & $\%$ & $\%$ & $\%$ & Average & $\%$ & $\%$ & $\%$ & Average & & \\
\hline Asp & 5.42 & 5.45 & 5.44 & 5.44 & 5.40 & 5.45 & 5.39 & 5.41 & -0.02 & -0.43 \\
\hline Thr & 1.88 & 1.96 & 1.94 & 1.93 & 1.87 & 1.87 & 1.87 & 1.8 & -0.06 & -3.03 \\
\hline Ser & 3.81 & 3.82 & 3.83 & 3.82 & 3.81 & 3.84 & 3.80 & 3.82 & 0.00 & -0.09 \\
\hline Glu & 9.07 & 9.17 & 9.14 & 9.13 & 9.22 & 9.19 & 9.21 & 9.21 & 0.08 & 0.87 \\
\hline Gly & 36.3 & 36.33 & 36.35 & 36.33 & 36.06 & 36.13 & 36.04 & 36.08 & -0.25 & -0.69 \\
\hline Ala & 12.10 & 12.22 & 12.17 & 12.16 & 12.15 & 12.11 & 12.08 & 12.11 & -0.05 & -0.41 \\
\hline Val & 2.70 & 2.70 & 2.71 & 2.70 & 2.68 & 2.67 & 2.68 & 2.68 & -0.03 & -1.00 \\
\hline Met & 0.69 & 0.57 & 0.69 & 0.65 & 0.66 & 0.67 & 0.67 & 0.67 & 0.02 & 2.50 \\
\hline Ile & 1.50 & 1.47 & 1.49 & 1.49 & 1.47 & 1.46 & 1.45 & 1.46 & -0.03 & -1.83 \\
\hline Leu & 3.00 & 2.98 & 2.99 & 2.99 & 3.00 & 2.99 & 2.98 & 2.99 & 0.00 & 0.00 \\
\hline Tyr & 0.28 & 0.31 & 0.28 & 0.29 & 0.30 & 0.32 & 0.33 & 0.32 & 0.03 & 8.42 \\
\hline Phe & 1.18 & 1.19 & 1.16 & 1.18 & 1.22 & 1.24 & 1.25 & 1.24 & 0.06 & 4.85 \\
\hline His & 0.52 & 0.50 & 0.51 & 0.51 & 0.50 & 0.53 & 0.51 & 0.51 & 0.00 & 0.65 \\
\hline Lys & 2.74 & 2.73 & 2.7 & 2. & 2.75 & 2.75 & 2.75 & 2.75 & 0.03 & 0.97 \\
\hline $\mathrm{Arg}$ & 5.52 & 5.50 & 5.54 & 5.52 & 5.61 & 5.57 & 5.72 & 5.63 & 0.11 & 2.01 \\
\hline Pro & 13.28 & 13.09 & 13.05 & 13.14 & 13.3 & 13.2 & 13.28 & 13.26 & 0.12 & 0.90 \\
\hline
\end{tabular}

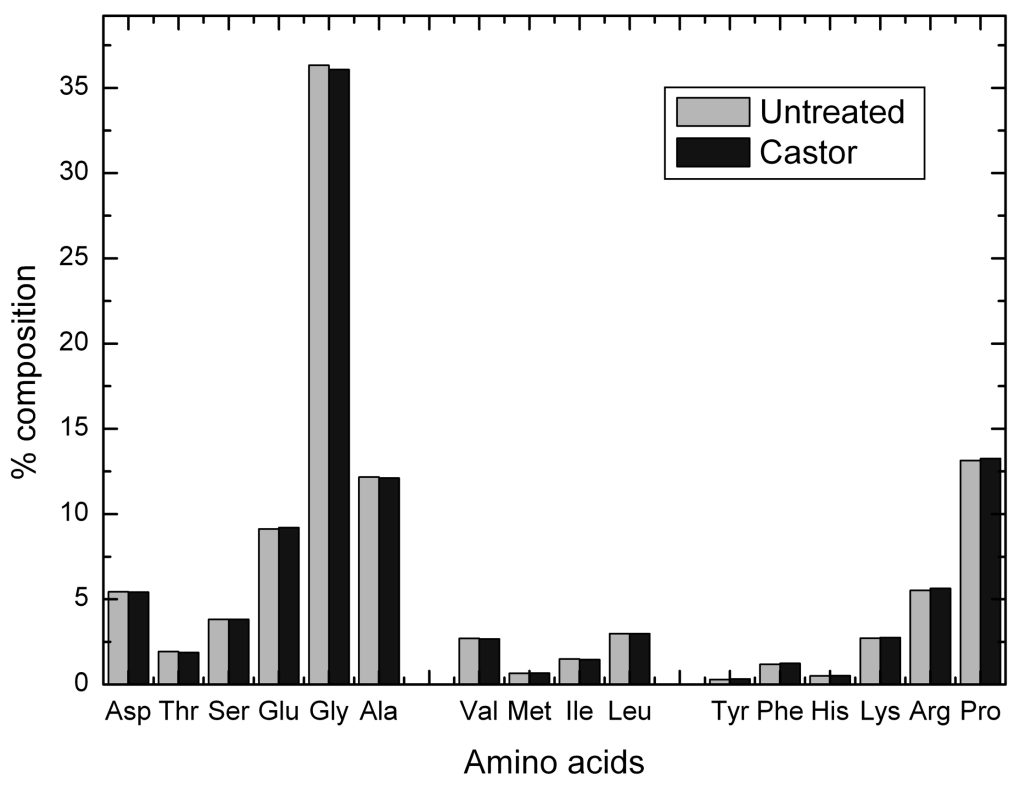

Figure 2 Composition of the proteins (percentages) of the 2 samples. The data are listed in Table 1. 


\section{RADIOCARBON DATING EXPERIMENTS}

${ }^{14} \mathrm{C}$ dating is the ultimate method to ascertain if a cleaning protocol has been effective in removing castor oil to an extent such that the resulting date of a Dead Sea Scroll is only altered by an insignificant amount. A pollution of $1 \%$ in weight of a sample with a ${ }^{14} \mathrm{C}$ age of $2000 \mathrm{BP}$ with a modern substance would yield a date $104{ }^{14} \mathrm{C}$ yr too young. A pollution of $0.1 \%$ would yield a date $10{ }^{14} \mathrm{C} \mathrm{yr}$ too young; and a pollution of $0.01 \%$ would yield a date that is only $1{ }^{14} \mathrm{C}$ yr too young.

From the perspective of present-day discussions in the Dead Sea Scrolls scholarly community, it would generally be thought that a contamination giving rise to a 104-yr offset is unacceptable, whereas an offset of only $1 \mathrm{yr}$ would be very acceptable indeed. There is hardly any question that the biblical scholars studying the Dead Sea Scrolls would be happy with an offset of less than a decade. However, it is not realistic to expect the accuracy of the uncalibrated age to be better than about 30 ${ }^{14} \mathrm{C}$ yr $(1 \sigma)$ for a large sample $(7-10 \mathrm{mg})$ and about $50{ }^{14} \mathrm{C}$ yr for a small sample $(3-4 \mathrm{mg})$.

Therefore, we conclude that a contamination of modern carbon in excess of $0.1 \mathrm{wt} \%$ is unacceptable. But if we can succeed in attaining a contamination threshold of $<0.1 \mathrm{wt} \%$, the potential offset in age attributable to contamination will be $<10{ }^{14} \mathrm{C}$ yr. Three different decontamination protocols using different extraction methods are described below, in which we have attempted to meet this threshold.

\section{CLEANING EXPERIMENT WITH SUPERCRITICAL $\mathrm{CO}_{2}$}

Extraction using supercritical $\mathrm{CO}_{2}$ as a solvent is known to be a very effective extraction method for many organic substances (Kiran et al. 2000; Sun et al. 2008). We have performed a series of cleaning experiments to determine if supercritical $\mathrm{CO}_{2}$ could be used to remove castor oil from parchment.

One modern parchment sample and 2 samples of medieval parchment of known age were included in this series of experiments. The modern sample is made from goat skin and procured in the normal way for parchment: the skin is stretched, scraped, and dried under tension, thus creating a stiff white to yellowish skin. It is not tanned. The medieval parchment is cut from a well-preserved French monastic manuscript, which judged from the text is estimated to originate from the middle of the 13th century, i.e. between AD 1200 and 1300 (E Petersen, personal communication, 1992).

The samples were weighed in their natural state (in which the sample potentially holds some water absorbed from the air). The 2 medieval samples were dried in an oven at $50{ }^{\circ} \mathrm{C}$ and $0 \%$ relative humidity overnight, and then weighed again (dry weight), thus enabling the calculation of their water content in the natural state. The modern test sample was only weighed in its natural state (with water). The modern parchment sample and 1 of the medieval samples (KLR-6857) were contaminated with castor oil and weighed again, allowing the determination of the weight of the castor oil added. The weights are listed in Table 2 .

At the Technical University of Denmark, the samples were subjected to supercritical $\mathrm{CO}_{2}$ at a pressure of 73.8 bars and a temperature of $35.0^{\circ} \mathrm{C}$ in a Hastelloy cylinder, a so-called Hassler-type core holder. The cylinder was kept in an air bath for temperature control and the pressure was produced with a high-pressure ISCO pump. One sample at a time was mounted in the high-pressure sample holder, sandwiched between 2 sheets of PVC filters $(0.02-0.03 \mathrm{~mm})$. The $\mathrm{CO}_{2}$ was flushed through

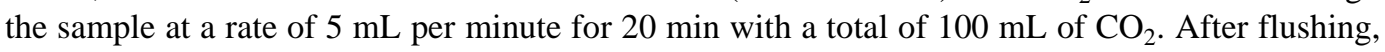
the samples were weighed, dried overnight in an oven at $35^{\circ} \mathrm{C}$ and $0 \%$ relative humidity, weighed again, and finally transferred to new containers. 
Table 2 Weights of the 3 samples subjected to cleaning in a flow of dense supercritical $\mathrm{CO}_{2}$. The first sample was a test sample, a piece of modern parchment with no laboratory number assigned. The next 2 samples were medieval parchment samples. Natural weight: initial weight of the pristine sample. Dry weight: weight of the sample after drying in $\sim 50{ }^{\circ} \mathrm{C}$ and $0 \% \mathrm{RH}$ for $\sim 30 \mathrm{~min}$. Weight with cont.: weight of the sample after contamination has been added. Weight of cont.: weight of the contaminating substance added to the sample, calculated as the difference of the preceding 2 weights (or in 1 case, the natural weight). Weight after cl.: weight of the contaminated sample after it has been subjected to the full cleaning procedure and dried. Weight removed: weight of the sample with contamination minus the weight after cleaning and drying, i.e. the weight of the contamination that has been removed plus the weight of parchment lost in the cleaning procedure.

\begin{tabular}{|c|c|c|c|c|c|c|c|c|c|}
\hline Sample & Treatment & $\begin{array}{l}\text { Natural } \\
\text { weight } \\
\text { (mg) }\end{array}$ & $\begin{array}{l}\text { Dry } \\
\text { weight } \\
(\mathrm{mg})\end{array}$ & $\begin{array}{l}\text { Weight } \\
\text { with } \\
\text { cont. } \\
\text { (mg) }\end{array}$ & $\begin{array}{l}\text { Weight } \\
\text { of } \\
\text { cont. } \\
\text { (mg) }\end{array}$ & $\begin{array}{l}\text { Before } \\
\mathrm{CO}_{2} \\
\text { clean } \\
(\mathrm{mg})\end{array}$ & $\begin{array}{l}\text { After } \\
\mathrm{CO}_{2} \\
\text { clean } \\
(\mathrm{mg})\end{array}$ & $\begin{array}{l}\text { After } \\
\text { drying } \\
\left(35^{\circ} \mathrm{C}\right) \\
(\mathrm{mg})\end{array}$ & $\begin{array}{l}\text { Weight } \\
\text { removed } \\
(\mathrm{mg})\end{array}$ \\
\hline $\begin{array}{l}\text { Modern parch- } \\
\text { ment }\end{array}$ & Castor oil & 13.0 & - & 14.2 & 1.2 & 14.2 & 14.0 & 12.6 & 1.6 \\
\hline KLR-6856 & Blank & 5.6 & 5.2 & 5.2 & 0.0 & 5.4 & 5.7 & 5.0 & 0.2 \\
\hline KLR-6857 & Castor oil & 6.4 & 6.1 & 7.9 & 1.8 & 8.1 & 7.0 & 6.0 & 1.9 \\
\hline
\end{tabular}

Judging from the sample weights, it is possible that in all 3 cases all the castor oil has been removed from the samples. For the modern parchment sample the initial dry weight is unknown, but it is still possible that all the castor oil has been removed from this sample as well. However, the question is how much parchment material has been lost in the course of the cleaning process.

For this, we made a simple model. Using $X$ as the amount in mg of castor oil removed and $Y$ the amount in $\mathrm{mg}$ of parchment fibers lost during the cleaning procedure, the "Weight removed" (see Table 2) can be written as:

$$
\text { Weight removed }=X+Y
$$

In the case of the blank sample (KLR-6856), we know that $X=0$, and that $Y$ therefore becomes $0.2 \mathrm{mg}$. If an equal weight of parchment material was also removed from sample KLR-6857, i.e. if we assume that $Y=0.2 \mathrm{mg}$, we then get for KLR-6857:

$$
X=\text { Weight removed }-Y=1.9-0.2=1.7 \mathrm{mg}
$$

For KLR-6857, the measured weight of the contamination was $1.8 \mathrm{mg}$. However, the difference between 1.7 and $1.8 \mathrm{mg}$ is at the uncertainty level of the scale; also there is an uncertainty in the estimation of $Y$ (the $0.2 \mathrm{mg}$ ), which may be significant. The numbers are thus in agreement with the scenario that all castor oil was removed by the supercritical $\mathrm{CO}_{2}$ cleaning procedure. Therefore, it was decided to subject the 2 medieval samples to the "ultimate test" of ${ }^{14} \mathrm{C}$ dating, the results of which are given in Table 3. The ${ }^{14} \mathrm{C}$ dates are reported in BP, rounded to the nearest 5; the ${ }^{14} \mathrm{C}$ activities (normalized for isotope fractionation) are reported in $\mathrm{F}^{14} \mathrm{C}$, also known as percent modern (van der Plicht and Hogg 2006).

Seen from a statistical view, a hypothesis of similar age between the 2 dates is accepted by a $t$ test. However, from the perspective of the Dead Sea Scroll studies, the fact that the sample contaminated with modern castor oil is ${ }^{14} \mathrm{C}$ dated to an age $45{ }^{14} \mathrm{C}$ yr younger than the date of the untreated sample discouraged us from pushing this cleaning method further at this stage. However, it is not excluded that the method of supercritical $\mathrm{CO}_{2}$ extraction could be made to work with another pressure and/or temperature and possibly using ethanol as a solvent instead of $\mathrm{CO}_{2}$. 
Table 3 Results of ${ }^{14} \mathrm{C}$ datings of the medieval samples cleaned in supercritical $\mathrm{CO}_{2}$. No artificial aging was applied to the samples prior to cleaning. The cleaning procedure: $\mathrm{SC} \mathrm{CO}_{2}=$ supercritical $\mathrm{CO}_{2}$. The ${ }^{14} \mathrm{C}$ age is given in $\mathrm{BP}$, rounded to the nearest 5 . The $\delta^{13} \mathrm{C}$ values are reported in per mil relative to the VPDB standard. $\mathrm{F}^{14} \mathrm{C}$ is the percent modern value relative to the standard activity value.

\begin{tabular}{lllllllll}
\hline SDU & GrA & & Artificial & $\begin{array}{l}\text { Cleaning } \\
\text { Lab nr }\end{array}$ & Lab nr & Contamination & & \multicolumn{2}{l}{$\delta^{13} \mathrm{C}$} \\
& aging & procedure & $\mathrm{BP}$ & $1 \sigma$ & $(\% \circ)$ & $\mathrm{F}^{14} \mathrm{C}$ \\
\hline KLR-6856 & 37896 & Untreated & None & $\mathrm{SC} \mathrm{CO}_{2}$ & 785 & 30 & -22.40 & $0.9070 \pm 0.0033$ \\
KLR-6857 & 37901 & Castor oil & None & $\mathrm{SC} \mathrm{CO}_{2}$ & 740 & 30 & -22.53 & $0.9118 \pm 0.0032$ \\
\hline
\end{tabular}

\section{CLEANING EXPERIMENT WITH 2 × 15 MINUTES IN HEXANE IN ULTRASOUND}

Initially, we assumed that the decisive factor was that castor oil or its derivatives had polymerized to large aggregates, which were trapped or locked in the 3-dimensional structure of the parchment. Seen from this perspective, even if it is not possible to dissolve the castor oil completely, it might be possible to remove the macromolecular compounds physically (mechanically) by exposing the sample to ultrasound while extracting in organic solvents, thus shaking out still undissolved molecules.

Our next cleaning protocol therefore consisted of placing the sample in a beaker with $\sim 50 \mathrm{~mL}$ of analytical-grade hexane and placing the beaker in water in an ultrasound bath operating at a frequency of $42 \mathrm{kHz}$ and with a continuous output of $100 \mathrm{~W}$. After $15 \mathrm{~min}$, the ultrasound was stopped and the sample transferred to a new beaker with a new batch of $\sim 50 \mathrm{~mL}$ hexane. The beaker was then placed in the ultrasound bath for another $15 \mathrm{~min}$, after which the sample was taken out and left to dry overnight and then weighed.

Our experiment using this protocol was conducted on samples from the same medieval parchment as used in the previous experiment and in the experiments of Rasmussen et al. (2001). For comparison, 2 samples (KLR-2525 and KLR-2527) were cleaned using only the AAA procedure in a manner similar to that of Bonani et al. (1992) and Jull et al. (1995). The AAA method by itself is insufficient to remove castor oil, as reported by Rasmussen et al. (2001). In the present experiment, however, we contaminated 2 samples (KLR-2524 and KLR-2525) with British Museum Leather Dressing (BMLD), and then 2 more samples with a combination of first castor oil and then BMLD, KLR-2526 and KLR-2527. The results of the sample weights of these experiments are shown in Table 4.

As can be seen from the columns "Weight of cont." and "Weight removed" in Table 4, the cleaning procedure removed significantly more weight than the weight of the contaminant(s) added for the first 4 samples. Only for sample KLR-2527 the same amount of weight was removed in the cleaning as was added as contamination: $3.4 \mathrm{mg}$ of castor oil plus $0.9 \mathrm{mg}$ of BMLD, totaling $4.3 \mathrm{mg}$, but in this case not all the contamination was removed, as can be seen below. These results are not surprising because the exposure to ultrasound for a total of $30 \mathrm{~min}$ is indeed a rough treatment for the rather delicate and fragile $\sim 770$-yr-old parchment sample. In comparison, cleaning with supercritical $\mathrm{CO}_{2}$ is much less disruptive.

The results of the ${ }^{14} \mathrm{C}$ datings of the ultrasound cleaning protocol are given in Table 5. It should be emphasized that no artificial aging was attempted prior to cleaning in this experiment.

It is clear from the data shown in Table 5 that the AAA pretreatment alone is unable to remove either BMLD alone or a combination of castor oil and BMLD together. These results confirm and reinforce the findings of Rasmussen et al. (2001), in which it was shown that AAA alone is not sufficient to remove castor oil contamination. For the samples that were subjected to $2 \times 15 \mathrm{~min}$ in hexane in ultra- 
Table 4 The treatments and sample weights of the cleaning experiments using $2 \times 15 \mathrm{~min}$ in hexane in ultrasonic bath on medieval parchment samples. Natural weight: initial weight of the pristine sample. Dry weight: not measured here. Weight with cont.: weight of the sample after contamination has been applied. Weight of cont.: weight of the contaminating substance added to the sample; C: castor oil, B: BMLD. Weight after cl.: weight of the contaminated sample after it has been subjected to the full cleaning procedure and dried. Weight removed: weight with contamination minus the weight after cleaning, i.e. weight of the contamination removed plus weight of parchment lost in the cleaning procedure.

\begin{tabular}{lllllllll}
\hline Sample & Contamination & $\begin{array}{l}\text { Artificial } \\
\text { aging }\end{array}$ & $\begin{array}{l}\text { Natural } \\
\text { weight } \\
(\mathrm{mg})\end{array}$ & $\begin{array}{l}\text { Dry } \\
\text { weight } \\
(\mathrm{mg})\end{array}$ & $\begin{array}{l}\text { Weight } \\
\text { with cont. } \\
(\mathrm{mg})\end{array}$ & $\begin{array}{l}\text { Weight } \\
\text { of cont. } \\
(\mathrm{mg})\end{array}$ & $\begin{array}{l}\text { Weight } \\
\text { after cl. } \\
(\mathrm{mg})\end{array}$ & $\begin{array}{l}\text { Weight } \\
\text { removed } \\
(\mathrm{mg})\end{array}$ \\
\hline KLR-2523 & Untreated & None & 18.8 & - & 18.8 & 0.0 & 15.0 & 3.8 \\
KLR-2524 & BMLD & None & 11.6 & - & 14.8 & 3.2 & 8.7 & 6.1 \\
KLR-2525 & BMLD & None & 11.6 & - & 14.2 & 2.6 & 10.7 & 3.5 \\
KLR-2526 & Castor+BMLD & None & 12.1 & - & $16.1 \mathrm{C}$ & $4.0 \mathrm{C}$ & 9.3 & 8.1 \\
& & & & & $17.4 \mathrm{~B}$ & $1.3 \mathrm{~B}$ & & \\
KLR-2527 & Castor+BMLD & None & 12.8 & - & $16.2 \mathrm{C}$ & $3.4 \mathrm{C}$ & 12.8 & 4.3 \\
& & & & & $17.1 \mathrm{~B}$ & $0.9 \mathrm{~B}$ & & - \\
\hline
\end{tabular}

Table 5 Results of the ${ }^{14} \mathrm{C}$ datings of the medieval samples cleaned in $2 \times 15 \mathrm{~min}$ in hexane in ultrasonic bath. The ${ }^{14} \mathrm{C}$ age is given in $\mathrm{BP}$, rounded to the nearest 5 . The $\delta^{13} \mathrm{C}$ values are reported in per mil relative to the VPDB standard. $\mathrm{F}^{14} \mathrm{C}$ is the percent modern value relative to the standard activity value.

\begin{tabular}{lllllllll}
\hline SDU & GrA & & Artificial & Cleaning & Age & \multicolumn{3}{l}{$\delta^{13} \mathrm{C}$} \\
Lab nr & Lab nr & Contamination & aging & procedure & BP & $1 \sigma$ & $(\%)$ & $\mathrm{F}^{14} \mathrm{C}$ \\
\hline KLR-2523 & 15055 & Untreated & None & Hex. $2 \times 15$ min US & 775 & 45 & -22.13 & $0.9081 \pm 0.0051$ \\
KLR-2524 & 15057 & BMLD & None & Hex. 2×15 min US & 740 & 45 & -22.46 & $0.9120 \pm 0.0052$ \\
KLR-2525 & 15058 & BMLD & None & AAA only & 360 & 45 & -23.50 & $0.9560 \pm 0.0053$ \\
KLR-2526 & 15060 & Castor+BMLD & None & Hex. 2x15 min US & 780 & 50 & -22.44 & $0.9078 \pm 0.0062$ \\
KLR-2527 & 15061 & Castor+BMLD & None & AAA only & 270 & 45 & -24.12 & $0.9672 \pm 0.0054$ \\
KLR-2528 & 15062 & Pure BMLD & - & - & - & - & -26.45 & $1.1326 \pm 0.0063$ \\
\hline
\end{tabular}

sound, the difference between KLR-2523 (untreated) and KLR-2524 (BMLD) is not statistically significant. However, as before with the supercritical $\mathrm{CO}_{2}$ extraction, there is a difference in the expected direction if the sample was still contaminated with BMLD towards a younger age, in this case, $35{ }^{14} \mathrm{C}$ yr. Even though it is within statistical limits, one may suspect that the BMLD was not removed completely. However, sample KLR-2526 has almost the same result as the untreated sample, KLR-2523. It is speculated that the sequence of exposure of the 2 contaminants might have played a role here such that the castor oil, which was added first, has acted as a coating or protection, preventing the BMLD from binding to the parchment. If this explanation is correct, we can conclude that the cleaning method (hexane in ultrasound bath) is sufficient to remove castor oil, but not BMLD.

The apparent success in removing the castor oil from the medieval parchment in an ultrasonic bath led us to conduct a new experiment using a real (uninscribed) small piece of Dead Sea Scroll parchment from Qumran Cave 4 kindly supplied to G Doudna by E Libman of the Israel Antiquity Authority. As this small piece of parchment was uninscribed, it is likely that it was not cleaned or exposed to castor oil or BMLD in the Scrollery at the Rockefeller Museum. The same ultrasound extraction protocol as described above was applied. The sample weights are listed in Table 6. 
Table 6 Treatments and sample weights of the cleaning experiments using $2 \times 15 \mathrm{~min}$ in hexane in ultrasonic bath on uninscribed Dead Sea Scroll parchment samples. Natural weight: initial weight of the pristine sample. Dry weight: not measured here. Weight with cont.: weight of the sample after contamination has been applied. Weight of cont.: weight of the contaminating substance added to the sample. Weight after cl.: weight of the contaminated sample after it has been subjected to the full cleaning procedure and dried. Weight removed: weight with contamination minus the weight after cleaning, i.e. the weight of the contamination removed plus the weight of parchment lost in the cleaning procedure.

\begin{tabular}{lllllllll}
\hline Sample & Contamination & $\begin{array}{l}\text { Artificial } \\
\text { aging }\end{array}$ & $\begin{array}{l}\text { Natural } \\
\text { weight } \\
(\mathrm{mg})\end{array}$ & $\begin{array}{l}\text { Dry } \\
\text { weight } \\
(\mathrm{mg})\end{array}$ & $\begin{array}{l}\text { Weight } \\
\text { with cont. } \\
(\mathrm{mg})\end{array}$ & $\begin{array}{l}\text { Weight } \\
\text { of cont. } \\
(\mathrm{mg})\end{array}$ & $\begin{array}{l}\text { Weight } \\
\text { after cl. } \\
(\mathrm{mg})\end{array}$ & $\begin{array}{l}\text { Weight } \\
\text { removed } \\
(\mathrm{mg})\end{array}$ \\
\hline KLR-2652 & Untreated & None & 26.1 & - & 26.1 & 0.0 & Lost & $(26.1)$ \\
KLR-2653 & Castor oil & None & 21.9 & - & 28.1 & 6.2 & 10.3 & 17.8 \\
KLR-2654 & BMLD & None & 23.5 & - & 27.9 & 4.4 & \multicolumn{1}{l}{ Lost } & $\begin{array}{l}(27.9) \\
\text { KLR-2655 }\end{array}$ \\
& BMLD+Castor & None & 22.2 & - & $27.3 \mathrm{~B}$ & $5.1 \mathrm{~B}$ & 12.3 & 16.0 \\
KLR-2657 & Untreated & None & 13.9 & - & 13.9 & 0.0 & 10.5 & 3.4 \\
KLR-2679 & Castor oil & None & 10.8 & - & 14.3 & 3.5 & 8.6 & 5.7 \\
KLR-2680 & BMLD & None & 16.4 & - & 19.4 & 3.0 & 11.9 & 7.5 \\
\hline
\end{tabular}

From the last column in Table 6, it is seen that a substantial amount of sample weight is lost, in all cases much in excess of the contamination added. Two out of the 7 samples were completely lost in this cleaning procedure. In these cases (KLR-2652 and KLR-2654), the parchment simply disintegrated to fibers so small that they were not visible to the naked eye. Such complete disintegration prevents the sample from undergoing pretreatment by the AAA method and dating. This disintegration is undoubtedly due to the rough mechanical treatment that the ultrasound has on the fragile 2000-yr old parchment. It thus seems that the Dead Sea Scrolls have less mechanical strength than the medieval French parchment.

The 5 samples that survived the ultrasound cleaning protocol were subjected to ${ }^{14} \mathrm{C}$ dating. The results are given in Table 7.

Table $7{ }^{14} \mathrm{C}$ dating results of the samples of uninscribed Dead Sea Scroll parchment samples subjected to $2 \times 15$ min cleaning in hexane in ultrasonic bath. The ${ }^{14} \mathrm{C}$ age is given in $\mathrm{BP}$, rounded to the nearest 5. The $\delta^{13} \mathrm{C}$ values are reported in per mil relative to the VPDB standard. $\mathrm{F}^{14} \mathrm{C}$ is the percent modern value relative to the standard activity value.

\begin{tabular}{|c|c|c|c|c|c|c|c|c|}
\hline $\begin{array}{l}\text { SDU } \\
\text { Lab nr }\end{array}$ & $\begin{array}{l}\text { GrA } \\
\text { Lab nr }\end{array}$ & Contamination & $\begin{array}{l}\text { Artificial } \\
\text { aging }\end{array}$ & $\begin{array}{l}\text { Cleaning } \\
\text { procedure }\end{array}$ & $\begin{array}{l}\text { Age } \\
\text { BP }\end{array}$ & $1 \sigma$ & $\begin{array}{l}\delta^{13} \mathrm{C} \\
(\% o)\end{array}$ & $\mathrm{F}^{14} \mathrm{C}$ \\
\hline KLR-2653 & GrA-15611 & Castor oil & None & Hex. $2 \times 15$ min US & 2090 & 50 & -17.29 & $0.7706 \pm 0.0051$ \\
\hline KLR-2655 & GrA-15612 & BMLD+Castor & None & Hex. $2 \times 15$ min US & 2020 & 60 & -17.27 & $0.7780 \pm 0.0051$ \\
\hline KLR-2657 & GrA-15613 & Untreated & None & Hex. $2 \times 15$ min US & 2000 & 70 & -17.50 & $0.7797 \pm 0.0065$ \\
\hline KLR-2679 & GrA-15614 & Castor oil & None & Hex. $2 \times 15$ min US & 1910 & 60 & -17.53 & $0.7886 \pm 0.0054$ \\
\hline KLR-2680 & Not dated & BMLD & None & Hex. $2 \times 15$ min US & - & - & - & - \\
\hline
\end{tabular}

The untreated Dead Sea Scroll parchment sample, KLR-2657, was dated to $2000 \pm 70$ BP. All the ${ }^{14} \mathrm{C}$ dates in this paper are calibrated with the WinCal25 calibration program (van der Plicht 2004) using the IntCal04 curves (Reimer et al. 2004), and the calibrated dates are reported as $1 \sigma(2 \sigma)$. The date of KLR-2657 calibrates to 90 BC-AD 75 (194 BC-AD 132), which is in good agreement with the expected time range of activity at Qumran. Two samples were contaminated with castor oil, 
KLR-2653 and KLR-2679. Sample KLR-2679 shows an age $90{ }^{14} \mathrm{C}$ yr younger than that of the untreated sample. However, KLR-2653, which was also contaminated with castor oil, yielded an age $90{ }^{14} \mathrm{C}$ yr older than the age of the untreated sample, and is thus $180{ }^{14} \mathrm{C}$ yr older than KLR-2679. The sample contaminated with both BMLD and castor oil (now with BMLD exposure first) showed an age very similar to the untreated sample. These numbers can be explained by statistical fluctuations as they can formally be accepted as identical by a $t$ test. Even so, we have to abandon this cleaning protocol, and probably this cleaning method altogether, because 2 out of 7 samples were lost, and a substantial amount of parchment material was lost from the rest of the samples.

\section{CLEANING EXPERIMENT WITH ETHANOL, HEXANE, AND ETHANOL IN SOXHLET EXTRACTION}

Due to the low survival rate of the samples, the mechanical ultrasound cleaning method was abandoned. We decided to try the mechanically more gentle Soxhlet extraction method. Here, the sample was placed inside the Soxhlet apparatus in a special manufactured grid of stainless steel precleaned in both ethanol and hexane in an ultrasonic bath. About $50 \mathrm{~mL}$ of ethanol was placed in the reservoir and heated to evaporation. The ethanol vapor was condensed on the cooling pipe and the hot liquid solvent dripped down onto the sample in the sample chamber of the Soxhlet. When the chamber was filled with $\sim 2 \mathrm{~mL}$, the liquid and its content of contaminants was emptied down into the reservoir. The protocol used was extraction in analytical-grade ethanol for $1 \mathrm{hr}$, analytical-grade hexane for 4 $\mathrm{hr}$, and analytical-grade ethanol for $1 \mathrm{hr}$. This way, the chamber was emptied approximately 30, 120, and 30 times, which means in total about 180 changes of solvent.

The Soxhlet extraction method has the distinct advantage that the dissolved contaminants are removed from the sample each time the solvent is emptied into the reservoir. In the cleaning protocol described in the previous section, the solvent was only renewed once.

The experiment was conducted in 2 rounds. The first round included 5 samples of the medieval parchment. The sample weights are listed in Table 8. One sample was left uncontaminated (KLR6850), one was contaminated with commercial castor oil alone (KLR-6851), and 1 sample (KLR6852) was contaminated with pure linoleic acid alone, which is the most reactive component of commercial castor oil, as described above (Figure 1). As linoleic acid is very reactive, and will polymerize even at room temperature, the vessel containing the linoleic acid was delivered to the laboratory in frozen form from the manufacturer and stored in our laboratory at $-20^{\circ} \mathrm{C}$ until $5 \mathrm{~min}$ before the sample was to be contaminated with the oil. The vessel containing $1 \mathrm{~mL}$ of linoleic acid was taken out of the freezer, brought to room temperature, and broken, after which the parchment sample was immediately exposed to 1 drop of the acid. It was ensured that the linoleic acid was clear and of low viscosity, ensuring that it had not yet polymerized. This contamination procedure was utilized in order to replicate a worst-case scenario, with a maximum of unpolymerized reactive linoleic acid present. Finally, 2 samples were contaminated with commercial castor oil and linoleic acid in the same way (KLR-6853 and KLR-6854) and were subsequently artificially aged after the contamination. The aging took place in a temperature raised to $60{ }^{\circ} \mathrm{C}$ and $0 \%$ relative humidity for 14 days. This was done in order to simulate a situation where samples exposed to commercial castor oil were stored in the warm climate in the Rockefeller Museum in Jerusalem for $~ 50 \mathrm{yr}$. It was thought that the castor oil could possibly take a longer time to polymerize than the times allowed for in our experiments in Denmark, in which there was typically a week to a month between contamination and initiation of the cleaning procedure and where the samples were stored at room temperature $\left(\sim 20^{\circ} \mathrm{C}\right)$. 
Table 8 The treatments and sample weights of the cleaning experiments using Soxhlet cleaning with $1 \mathrm{hr}$ in ethanol, $4 \mathrm{hr}$ in hexane, and $1 \mathrm{hr}$ in ethanol on medieval parchment samples (the first 5) and uninscribed Dead Sea Scroll samples (the last 2). Natural weight: initial weight of the pristine sample. Dry weight: weight of the sample after drying in $\sim 50{ }^{\circ} \mathrm{C}$ for $\sim 30 \mathrm{~min}$. Weight with cont.: weight of the sample after contamination has been applied. Weight of cont.: weight of the contaminating substance added to the sample. Weight after cl.: weight of the contaminated sample after it has been subjected to the full cleaning procedure and dried. Weight removed: weight with contamination minus the weight after cleaning, i.e. the weight of the contamination removed plus the weight of parchment lost in the cleaning procedure.

\begin{tabular}{lllllllll}
\hline Sample & Contamination & $\begin{array}{l}\text { Artificial } \\
\text { aging }\end{array}$ & $\begin{array}{l}\text { Natural } \\
\text { weight } \\
(\mathrm{mg})\end{array}$ & $\begin{array}{l}\text { Dry } \\
\text { weight } \\
(\mathrm{mg})\end{array}$ & $\begin{array}{l}\text { Weight } \\
\text { with cont. } \\
(\mathrm{mg})\end{array}$ & $\begin{array}{l}\text { Weight } \\
\text { of cont. } \\
(\mathrm{mg})\end{array}$ & $\begin{array}{l}\text { Weight } \\
\text { after cl. } \\
(\mathrm{mg})\end{array}$ & $\begin{array}{l}\text { Weight } \\
\text { removed } \\
(\mathrm{mg})\end{array}$ \\
\hline KLR-6850 & Untreated & None & 6.1 & 5.8 & 5.8 & 0.0 & 5.4 & 0.4 \\
KLR-6851 & Castor oil & None & 7.6 & 7.1 & 9.0 & 1.9 & 7.2 & 1.8 \\
KLR-6852 & Linoleic acid & None & 5.9 & 5.7 & 6.9 & 1.2 & 5.7 & 1.2 \\
KLR-6853 & Castor oil & $60^{\circ} \mathrm{C} 14 \mathrm{~d}$ & 8.5 & 7.9 & 9.0 & 1.1 & 7.7 & 1.3 \\
KLR-6854 & Linoleic acid & $60^{\circ} \mathrm{C} 14 \mathrm{~d}$ & 8.0 & 7.5 & 9.6 & 2.1 & 7.2 & 2.4 \\
KLR-7080 & Untreated & $60^{\circ} \mathrm{C} 14 \mathrm{~d}$ & 4.9 & 5.0 & 5.0 & 0.0 & 4.3 & 0.7 \\
KLR-7081 & Castor oil & $60^{\circ} \mathrm{C} 14 \mathrm{~d}$ & 5.8 & 5.7 & 7.8 & 2.1 & 3.9 & 3.9 \\
\hline
\end{tabular}

As can be seen from the last column in Table 8 , the amount of weight removed by the cleaning procedure is in all cases either only slightly larger than or comparable to the amount of contamination added. The Soxhlet cleaning protocol therefore appears to be much more mechanically gentle than the ultrasound cleaning protocol.

The results of the ${ }^{14} \mathrm{C}$ dates on these samples are listed in Table 9. Sample KLR-6854 was lost in the dating process due to technical problems. The dates of the other 4 samples are very similar-almost identical-showing that the cleaning was completely effective. The loss of the ${ }^{14} \mathrm{C}$ date for sample KLR-6854 was not too great a disadvantage, because that sample was contaminated with linoleic acid and artificially aged, and there is little doubt that linoleic acid, which is very reactive indeed, would have reacted fully within the 2 -week period that passed between the contamination and the initiation of the cleaning procedure, thus in fact duplicating sample KLR-6852. It is significant that both the samples contaminated with linoleic acid (KLR-6852), and commercial castor oil undergoing artificial aging (KLR-6853), yield results completely identical to the uncontaminated sample (KLR-6850).

In the final round of this experiment, we divided a sample from the same uninscribed Dead Sea Scroll piece into 2 subsamples. One was left untreated (KLR-7080), and the other was contaminated with commercial castor oil (KLR-7081). Both samples were artificially aged at $60{ }^{\circ} \mathrm{C}$ and $0 \%$ relative humidity for 14 days, after which they were cleaned in the Soxhlet equipment by the protocol described above. The samples were quite small, $\sim 4 \mathrm{mg}$. Nevertheless, 2 dates were obtained with an uncertainty of $\pm 70{ }^{14} \mathrm{C}$ yr. The sample weights are listed in Table 8 and the resulting ${ }^{14} \mathrm{C}$ dates in Table 9. The dates yield identical results within the experimental uncertainty.

Thus, the decontamination protocol described here (Soxhlet extraction) has proven to be effective in removing castor oil from Dead Sea Scroll parchment samples, and yet at the same time it is sufficiently mechanically gentle not to damage the parchment during the process. 
Table $9{ }^{14} \mathrm{C}$ dating results of the samples cleaned using Soxhlet cleaning with $1 \mathrm{hr}$ in ethanol, $4 \mathrm{hr}$ in hexane, and $1 \mathrm{hr}$ in ethanol on 5 samples of medieval parchment and 2 samples and uninscribed Dead Sea Scroll samples. The ${ }^{14} \mathrm{C}$ age is given in BP, rounded to the nearest 5 . The $\delta^{13} \mathrm{C}$ values are reported in per mil relative to the VPDB standard. $\mathrm{F}^{14} \mathrm{C}$ is the percent modern value relative to the standard activity value.

\begin{tabular}{lllllllll}
\hline $\begin{array}{l}\text { SDU } \\
\text { Lab nr }\end{array}$ & GrA & Lab nr & Contamination & $\begin{array}{l}\text { Artificial } \\
\text { aging }\end{array}$ & $\begin{array}{l}\text { Cleaning } \\
\text { procedure }\end{array}$ & $\begin{array}{l}\text { Age } \\
\text { BP }\end{array}$ & \multicolumn{3}{c}{$\delta^{13} \mathrm{C}$} \\
\hline KLR-6850 & 37802 & Untreated & None & Soxhlet E+H+E & 795 & 30 & -22.14 & $0.9059 \pm 0.0033$ \\
KLR-6851 & 37803 & Castor oil & None & Soxhlet E+H+E & 795 & 30 & -22.02 & $0.9059 \pm 0.0033$ \\
KLR-6852 & 37897 & Linoleic acid & None & Soxhlet E+H+E & 785 & 30 & -22.21 & $0.9071 \pm 0.0034$ \\
KLR-6853 & 37898 & Castor oil & $60^{\circ} \mathrm{C} 14 d$ & Soxhlet E+H+E & 795 & 30 & -22.03 & $0.9060 \pm 0.0036$ \\
KLR-6854 & 37899 & Linoleic acid & $60^{\circ} \mathrm{C} 14 \mathrm{~d}$ & Soxhlet E+H+E & (failed) & - & -21.98 & - \\
KLR-7080 & 39727 & Untreated & $60^{\circ} \mathrm{C} 14 \mathrm{~d}$ & Soxhlet E+H+E & 2120 & 70 & -18.47 & $0.7673 \pm 0.0065$ \\
KLR-7081 & 39728 & Castor oil & $60^{\circ} \mathrm{C} 14 \mathrm{~d}$ & Soxhlet E+H+E & 2200 & 70 & -18.11 & $0.7600 \pm 0.0065$ \\
\hline
\end{tabular}

\section{SUGGESTIONS FOR REDATING OF SELECTED DEAD SEA SCROLLS}

Several of the previous dates of Dead Sea Scroll samples have been noted as possibly erroneous and are obvious candidates for redating with the new decontamination protocol designed to ensure a complete removal of castor oil potentially present on these parchments. Ideally, it would be advantageous to clean and redate all Dead Sea Scrolls that have previously been dated and that have been kept in the Rockefeller Museum and therefore potentially exposed to castor oil contamination. However, this is probably not a very realistic first approach seen from the perspectives of the authorities taking care of the Scrolls. What we wish to suggest is to clean and redate samples from a smaller number of Scrolls that appear to show discrepancies with reported paleographic datings, which are commonly assumed to have an error margin in their age determination of some 25-50 yr. We have made a short list of 7 scrolls that would test whether the previously determined ${ }^{14} \mathrm{C}$ ages have been offset towards modern values based on the criteria listed below. The list comprises:

1. 4Q258 Community Rule ${ }^{d}$, dated at Tucson: $1823 \pm 24$ BP, calibrated to AD 138-230 at 1- $\sigma$ confidence interval (AD 132-239 at $2 \sigma$ ). Reason for suspicion \#1: The ${ }^{14} \mathrm{C}$ date is younger than scholars believe were the true ages of Qumran texts. Reason for suspicion \#2: Due to reason \#1, a second sample from the same text (4Q258) was cut and dated, producing the date $1964 \pm$ $35 \mathrm{BP}$, significantly older than the date of the first sample from 4Q258. In the opinion of most analysts, the date of the first sample from 4Q258 is in error. In addition, the Tucson laboratory reported visible glue contamination of $4 \mathrm{Q} 258$ prior to pretreatment. The sample was cleaned until all glue was believed to be gone. Despite neither the existence nor the identity of a contaminant affecting the ${ }^{14} \mathrm{C}$ dating of the first sample of $4 \mathrm{Q} 258$ having been verified, virtually all Qumran scholars reject this ${ }^{14} \mathrm{C}$ date.

2. 4Q266 Damascus Document ${ }^{\mathrm{a}}$, dated at Tucson: $1954 \pm 38$ BP, calibrated to AD 4-80 (38 BC$\mathrm{AD} 126$ at $2 \sigma$ ). Reason for suspicion \#1: This ${ }^{14} \mathrm{C}$ date is younger than the reported paleographic dating for this text. It "can be no later than the first half of the first century BC ... before the Roman conquest of 63 BC ... by palaeographical evidence" (Cross 1995:96); and: "the first half or to the middle of the first century BC" (Yardeni 1996:26-30). This paleographic dating for 4Q266 has been and continues to be widely cited by Qumran text scholars (the ${ }^{14} \mathrm{C}$ date notwithstanding) as perhaps the most fundamental perceived evidence for a completed composition date prior to the middle of the 1st century BC for the Damascus Document, which is regarded as one of the most important Dead Sea Scroll texts (e.g. Wasson 2005:23). Unlike other paleographic datings of Qumran texts based on dates assigned to chronologically "float- 
ing" formal hands (their dates of flourishing reconstructed indirectly since there is no known dated Hebrew text in a formal hand in the 2-century period $150 \mathrm{BC}$ to AD 50), 4Q266 was written in what is called a "semicursive" hand. Unlike the formal hands, "semicursive" does have dated comparative parallels in the centuries at issue on the basis of which paleographic dating experts have concluded that no semicursive hand in a Qumran text postdates the 1st century BC (Cross 1961:182, 188, 1998:401; Yardeni 1997:155) — whether that of 4Q266 or any other. Therefore, more is at stake in the conflicting ${ }^{14} \mathrm{C}$ and paleographic datings of $4 \mathrm{Q} 266$ than may immediately be realized. Reason for suspicion \#2: The question has been raised by a few scholars whether any texts found in the caves of Qumran postdate the 1st century BC (Doudna 1998, 2006; Young 2002, 2005; Crown 2005).

3. 4Q171 Pesher Psalms ${ }^{\mathrm{a}}$, dated at Tucson: $1944 \pm 23$ BP, calibrated to AD 28-77 (AD 5-123 at $2 \sigma$ ). Reason for suspicion \#1: This ${ }^{14} \mathrm{C}$ date on $4 \mathrm{Q} 171$ was the second youngest ${ }^{14} \mathrm{C}$ date for a Qumran text in the Zurich and Tucson series. The fact that the actual youngest Qumran text date (4Q258, see above) is almost universally considered too young justifies redating of this one too. Reason for suspicion \#2: The ${ }^{14} \mathrm{C}$ date of $4 \mathrm{Q} 171$ is significantly younger than that for $1 \mathrm{Q}$ Pesher Habakkuk (2054 $\pm 22 \mathrm{BP}$, calibrated to 95-2 BC (157 BC-AD 2 at $2 \sigma)$ ). Some scholars think that these 2 text copies are likely to be contemporaneous (see e.g. discussion in Doudna 1998). Reason for suspicion \#3: Recently, Ada Yardeni, an authority on the paleography of the Dead Sea texts, identified over 50 Qumran texts written by the same scribe who wrote 4Q171 Pesher Psalms ${ }^{\mathrm{a}}$ (Yardeni 2007). Without citing ${ }^{14} \mathrm{C}$ dates, Yardeni (2007:288) states that "it appears that our scribe was one of the most prolific copyists active in Qumran in the late first century BCE." (Later in the article, Yardeni estimates this scribe's activity period as "late first century BCE to the beginning of the first century CE.") The ${ }^{14} \mathrm{C}$ date of $4 \mathrm{Q} 171$ appears young compared to this paleographic date estimate. Reasons for suspicion \#4 and \#5: Two other texts identified by Yardeni as written by the same scribe who wrote 4Q171 were dated in the Zurich and Tucson series. One was 4Q267 Damascus Document ${ }^{\mathrm{b}}$, dated at Tucson to $2094 \pm 29 \mathrm{BP}$, which calibrates to 164-57 BC (190-44 BC at $2 \sigma)$. The other was the Joshua Apocryphon found at Masada, dated by Zurich to $2086 \pm 28 \mathrm{BP}$, which calibrates to $160-53 \mathrm{BC}(166-41 \mathrm{BC}$ at $2 \sigma)$. Both of these ${ }^{14} \mathrm{C}$ dates are significantly older than the ${ }^{14} \mathrm{C}$ date for $4 \mathrm{Q} 171$. Reason for suspicion \#6: Another of the texts written by the scribe who wrote 4Q171, according to Yardeni, was 4Q471b Self Glorification Hymn. It was separately ${ }^{14} \mathrm{C}$ dated in 2000 at Tucson at the request of Magen Broshi and Hanan Eshel. Broshi and Eshel reported that 4Q471b gave a ${ }^{14} \mathrm{C}$ date of "between 168 and 49 B.C." (Broshi and Eshel 2001). All of these ${ }^{14} \mathrm{C}$ dates on texts identified by Yardeni as written by the same scribe agree with each other except for the significantly younger ${ }^{14} \mathrm{C}$ date for 4Q171. Reason for suspicion \#7: the question has been raised by a few scholars whether any text copies found in the caves of Qumran postdate the 1st century BC. 4Q171 Pesher Psalms ${ }^{\mathrm{a}}$ was worked on and published in the 1950s by John Allegro, a known castor oil user. Was the ${ }^{14} \mathrm{C}$ date for $4 \mathrm{Q} 171$ affected by castor oil contamination?

4. 4Q521 Messianic Apocalypse, dated at Tucson $1984 \pm 33$ BP, calibrated to 35 BC-AD 55 (45 $\mathrm{BC}-\mathrm{AD} 75$ at $2 \sigma$ ). Reason for suspicion $\# 1$ : The ${ }^{14} \mathrm{C}$ date is significantly younger than the paleographic date assigned to this text of "dans le premier quart de 1er s., entre 100 et 80 " [between 100 and $80 \mathrm{BC}$ ] (Puech 1992). Reason for suspicion \#2: The question has been raised by a few scholars whether any texts found in the caves of Qumran postdate the 1st century BC.

5. 4Q258 Community Rule ${ }^{\mathrm{d}}$ second sample, dated at Tucson $1964 \pm 45 \mathrm{BP}$, calibrated to $35 \mathrm{BC}-$ AD 78 (49 BC-AD 129 at $2 \sigma$ ). Reason for suspicion \#1: The grounds for suspecting the ${ }^{14} \mathrm{C}$ date of the original sample of 4Q258 (see above) raise the question whether the second sample from that text was free of all effects of whatever affected the first sample, as distinguished from possibly being affected by the same contaminant to a lesser degree. Reason for suspicion \#2: A 
few scholars have questioned whether any texts found in the caves of Qumran postdate the 1st century BC.

6. XHev/Se 8a "Kefar Bebayou"/“Kefar Baru," dated at Tucson $1758 \pm 36$ BP, calibrated to AD 237-335 (AD 140-386 at $2 \sigma$ ). Reason for suspicion \#1: This document is not from Qumran and is a deed of sale of a house. Unlike the other texts, it bears an internal date, corresponding to $\mathrm{AD} 134 / 135$. The internal date of this autograph copy written on short-lived papyrus is considered by all authorities to be undisputed. Yet the ${ }^{14} \mathrm{C}$ age for this text is significantly younger than this text's known age. This text was 1 of 3 internally dated documents from other Dead Sea sites provided to the Tucson AMS facility for dating (without informing the lab prior to ${ }^{14} \mathrm{C}$ dating of their dates), as a check on the accuracy of the ${ }^{14} \mathrm{C}$ dates. (The other 2 documents in the Tucson series ${ }^{14} \mathrm{C}$ dated in agreement with their internal dates.) Carmi (2002) argued that the ${ }^{14} \mathrm{C}$ date for $\mathrm{XHev} / \mathrm{Se} 8 \mathrm{a}$ "is acceptable, but not desirable, by current standards of ${ }^{14} \mathrm{C}$ dating" and "does not indicate a problem with castor oil contamination" because there is a small possibility the calibrated age range distribution could correspond to the historical date. However, this particular document was worked on and separately published in 1957 by Joseph Milik, a known castor oil user. Again, was this text's ${ }^{14} \mathrm{C}$ dating affected by contamination from castor oil?

7. 1Q Thanksgiving Hymns ${ }^{\mathrm{a}}\left(1 \mathrm{QH} \mathrm{H}^{\mathrm{a}}\right)$, dated at Zurich $1979 \pm 32 \mathrm{BP}$, calibrated to $33 \mathrm{BC}-\mathrm{AD} 60$ (42 BC-AD 75 at $2 \sigma$ ). This is the youngest ${ }^{14} \mathrm{C}$ age reported among the 8 Qumran texts dated at Zurich. All of the items listed above (1-6) are from the Tucson series. $1 \mathrm{QH}^{\mathrm{a}}$ was not worked on at the Rockefeller Museum in the 1950s where texts were exposed to castor oil. Magen Broshi, Curator of the Shrine of the Book at the Israel Museum from 1964 to 1994, has stated that no text at the Israel Museum, such as $1 \mathrm{QH}^{\mathrm{a}}$, was exposed to castor oil (Rasmussen et al. 2001:128; Broshi 2004:135). Nevertheless, the Tucson date list suggests that a date later than 1st century BC for a Qumran text is an independent ground for suspicion (see above). So, did $1 \mathrm{QH}^{\mathrm{a}}$ yield the youngest Qumran text age among the 8 dated at Zurich because it is in fact a little younger than all of the others, or was it one of a number of text copies that are actually contemporary but only appear to be slightly younger because of statistics? Paleographically, $1 \mathrm{QH}^{\mathrm{a}}$ is characterized by Cross (1961:199) as a "developed Herodian formal," a scribal hand type estimated by Cross to have been in use about AD 20-50, later than "early Herodian formal" estimated by Cross at about $30 \mathrm{BC}-\mathrm{AD} 20$, but prior to a distinct, still more developed stage of formal hand named by Cross "Late Herodian formal" said to be AD 30-68 (Cross 1961:139; Cross and Eshel 2000:497). On the basis of these date assignments, it is widely believed by Qumran scholars that $1 \mathrm{QH}^{\mathrm{a}}$ was produced by a scribe in the 1st century $\mathrm{AD}$ ("The script proves it to belong to the first century AD," Vermes 1977:56). But is this traditional paleographic dating scheme correct which causes scholars to suppose that $1 \mathrm{QH}^{\mathrm{a}}$ is a 1 st century AD copy? It would be of interest to find out. No Qumran text written in "Late Herodian formal" was represented in either the Zurich or Tucson series. However, in 2000 a ${ }^{14} \mathrm{C}$ date for a text written in "Late Herodian formal," XJoshua (believed to be from Qumran), was published by J Charlesworth in the Oxford University Press's Discoveries in the Judean Desert volume 38. Paleographically, XJoshua was described as "similar to either 4QDeut (ca. 50 CE) or 4QPs ${ }^{\mathrm{b}}$ (ca. 50 to $68 \mathrm{CE}$ ) ... late Herodian formal book-hand (40 BCE - $68 \mathrm{CE}$, most likely near the end of the range)" (Charlesworth 2000:232, 234). The ${ }^{14} \mathrm{C}$ date of XJoshua, done at Tucson, was $2020 \pm 45 \mathrm{BP}$, calibrated to $87 \mathrm{BC}-\mathrm{AD} 51$ (161 BC-AD 69 at $2 \sigma)$. This ${ }^{14} \mathrm{C}$ date on the latest formal hand of the Qumran texts suggests an older age than believed by most Qumran scholars. For this reason, we believe it is worthwhile to redate $1 \mathrm{QH}^{\mathrm{a}}$, even if there is no reason to believe that this text was contaminated. Can a 1st century AD date of a scribal copy of a literary text from the Qumran caves be confirmed? 
It is not just a theoretical exercise that the previously published series of ${ }^{14} \mathrm{C}$ dates of Qumran text samples possibly contain dates of contaminated parchments, making some of them too young. The cases listed above (except for the last one) show grounds for suspecting possible individual cases. Our goal is not to challenge the validity of the ${ }^{14} \mathrm{C}$ dating method for dating Dead Sea Scrolls. We wish to identify and offer solutions to obstacles to accurate datings of Dead Sea scroll texts, so that ${ }^{14} \mathrm{C}$ dating can be done on Dead Sea texts with greater accuracy.

Furthermore, we would venture to question the assumption that all texts not in the Rockefeller Museum were "not treated with castor oil" (Carmi 2002), an assumption also corroborated by Magen Broshi about Dead Sea texts stored at the Israel Museum: "no castor oil was applied" (Broshi 2004). To substantiate this suspicion, we would like to quote an early description of cleaning methods in use as fragments of scrolls came into the Rockefeller Museum during the early 1950s: "When pieces are selected for study, they are first put into a 'humidifier,' a glass bell containing moist sponges. This process softens the scrap so that it will not crumble when handled. When softened, the pieces are next cleaned with a soft brush dipped in alcohol or castor oil" (Honour 1956:149-50). Again, "At one end of the room, the fragments are prepared for mounting. Those too brittle to be uncurled are placed in a humidifier until they are pliable enough to be pressed flat. Then they are cleaned of sand, mould and marl (a clayey sediment) with fine camel's-hair brushes, sometimes dipped in castor oil" (Time magazine, April 15, 1957).

The process with the humidifier was used on at least 1 badly damaged scroll acquired by Hebrew University, which ended up in the Israel Museum: 1Q Genesis Apocryphon (1QApGen): "The Hebrew University went to great lengths to unroll this badly crushed scroll [1QApGen], and they enlisted the aid of the famous German expert on ancient documents, Professor James Biberkraut. Professor Biberkraut placed the scroll under glass and slowly increased the humidity within the glass enclosure until, after several months of scientifically controlled humidity, the leather was sufficiently pliable to allow gentle, painstaking unrolling" (Honour 1956:138).

We must ask whether badly damaged scrolls that ended up in the Israel Museum were cleaned when humidified and unrolled. We note that published recommendations from conservators have emphasized the importance of cleaning dirt from parchment when humidifying (e.g. Kite and Thomson 2005). Is it plausible that whereas scrolls were humidified and cleaned with castor oil and a brush in the Rockefeller Museum, they were instead left uncleaned when humidified in the cases of texts now in the Israel Museum? Can we be sure that castor oil was not used-a compound that was widely used and recommended for cleaning purposes, considering that colleagues working on identical types of texts in the same city at the same time were using castor oil?

We propose to redate the texts listed above by ${ }^{14} \mathrm{C}$ dating, using a decontamination protocol that is proven to satisfactorily remove castor oil contamination, such as the protocol set forth in this paper. Redatings could reinforce the validity of individual ${ }^{14} \mathrm{C}$ dates as originally reported or could produce more accurate datings. Either way, important new information would be obtained on the age of the Dead Sea Scrolls.

\section{CONCLUSIONS}

The original editors working on the Dead Sea Scrolls in the 1950s, Frank Cross Jr, John Strugnell, and John Allegro, each reported the application of castor oil by themselves and some of their colleagues (e.g. Joseph Milik) on the scrolls for cleaning the fragments. These eyewitness reports, augmented by the findings of Rasmussen et al. (2001), which showed that the AAA pretreatment procedure was not sufficient to remove castor oil from parchment samples, moved us to develop a 
decontamination protocol that will allow a complete removal of castor oil from small samples of Dead Sea Scroll parchments.

Based on quantitative amino acid analysis of an untreated sample and a castor oil-contaminated sample of modern parchment, we conclude that it is very unlikely that a significant reaction takes place between any of the fatty acids of commercial castor oil and any of the amino acids present in the proteins of modern parchment. This leaves as the most likely possibility a dimerization or polymerization reaction between the components of the commercial castor oil.

The mechanically most effective method of removing castor oil from parchment samples is that of solvents in ultrasonic bath. Even though we have proven this method effective for medieval parchment samples, much parchment material was lost in this mechanically rough extraction method. It appears too rough for the more fragile Dead Sea Scroll parchments, and we cannot recommend using this method for cleaning samples of the Dead Sea Scrolls.

The cleaning method using supercritical $\mathrm{CO}_{2}$ is much gentler than the ultrasound method. In the method we have tested, the sample is initially flattened when mounting it in the high-pressure sample holder, but following this, the sample is kept very stable and fixated during the flushing with dense supercritical $\mathrm{CO}_{2}$. Even though we have not succeeded in making a perfect decontamination with the present protocol using this method, the method has the potential of being both gentle enough and effective enough. However, it requires more experimentation with varying pressure, temperature, and/or flushing time.

The Soxhlet extraction method can be ranked somewhere in between the 2 other methods in terms of physical and mechanical stress on the parchment. In this work, we have succeeded in devising a protocol using Soxhlet extraction that allows complete removal of commercial castor oil and linoleic acid from both a medieval parchment and from samples of uninscribed Dead Sea Scroll samples.

Based on our results, we recommend that a new batch of Dead Sea Scrolls be sampled, decontaminated by the protocol described in this paper, and ${ }^{14} \mathrm{C}$ dated. A list is provided of 7 Dead Sea texts that would be of primary concern in this respect. A secure decontamination and redating of selected Dead Sea Scrolls would remove the uncertainty left by the 2 previous batteries of dates on possibly insufficiently decontaminated scroll samples.

\section{ACKNOWLEDGMENTS}

Tran Thuong Dang is thanked for technical assistance in connection with the cleaning experiments using supercritical $\mathrm{CO}_{2}$. Discussions and input from Barbara Wills, Magen Broshi, Frank M Cross Jr, John Strugnell, Jan Gunneweg, Ira Rabin, Pnina Shor, and Elaine Libman are greatly appreciated.

\section{REFERENCES}

Bonani G, Ivy S, Wölfli W, Broshi M, Carmi I, Strugnell J. 1992. Radiocarbon dating of fourteen Dead Sea Scrolls. Radiocarbon 34(3):843-9.

Broshi M. 2004. The Dead Sea Scrolls, the sciences and new technologies. Dead Sea Discoveries 11(2):13342.

Broshi M, Eshel H. 2001. A messiah before Jesus Christ. Book review of I. Knohl, The Messiah Before Jesus. Tarbiz 70:133-8. In Hebrew.
Carmi I. 2002. Are the ${ }^{14} \mathrm{C}$ dates of the Dead Sea Scrolls affected by castor oil contamination? Radiocarbon 44(1):213-6.

Charlesworth JH. 2000. XJoshua. In: Charlesworth J, Cohen N, Cotton H, Eshel E, Eshel H, Flint P, Misgav $\mathrm{H}$, Morgenstern M, Murphy K, editors. Miscellaneous Texts from the Judean Desert. Discoveries in the Judean Desert 38. Oxford: Clarendon. p 231-9.

Cross FM. 1961. The development of the Jewish scripts. 
In: Wright GE, editor. The Bible and the Ancient Near East: Essays in Honor of W.F. Albright. Garden City: Doubleday. p 133-202.

Cross FM. 1995. The Ancient Library of Qumran. 3rd edition. Minneapolis: Fortress.

Cross FM. 1998. Palaeography and the Dead Sea Scrolls. In: Flint PW, VanderKam JC, editors. The Dead Sea Scrolls after Fifty Years. Volume 1. Leiden: Brill. p 379-402.

Cross FM, Eshel E. 2000. KhQOstracon. In: Alexander P, VanderKam J, Brady M, editors. Miscellanea, Part I. Discoveries in the Judean Desert 36. Oxford: Clarendon Press. p 497-507.

Crown AD. 2005. An alternative view of Qumran. In: Bar-Asher M, Florentin M, editors. Samaritan, Hebrew and Aramaic Studies: Presented to Professor Abraham Tal. Jerusalem: Bialik Institute. p 1-24.

Doudna G. 1998. Dating the Scrolls on the basis of radiocarbon analysis. In: Flint PW, VanderKam JC, editors. The Dead Sea Scrolls after Fifty Years. Volume 1. Leiden: Brill. p 430-71.

Doudna G. 2006. The legacy of an error in archaeological interpretation. the dating of the Qumran Cave Scroll deposits. In: Galor K, Humbert J-B, Zangenberg J, editors. The Site of the Dead Sea Scrolls: Archaeological Interpretations and Debates. Leiden: Brill. p 147-57.

Honour A. 1956. Cave of Riches: The Story of the Dead Sea Scrolls. New York: McGraw-Hill.

Jull AJT, Donahue DJ, Broshi M, Tov E. 1995. Radiocarbon dating of scrolls and linen fragments from the Judean desert. Radiocarbon 37(1):11-9.

Kiran E, Debenedetti PG, Peters CJ. 2000. Supercritical Fluids: Fundamentals and Applications. NATO science series. Series E, Applied Sciences. Dordrecht: Kluwer. 366 p.

Kite M, Thomson R, editors. 2005. Conservation of Leather and Related Materials: And Related Materials. Oxford: Butterworth-Heinemann.

Puech E. 1992. Une apocalypse messianique (4Q 521). Revue de Qumran 60:475-519.

Rasmussen KL, van der Plicht J, Cryer FH, Doudna G, Cross FM, Strugnell J. 2001. The effects of possible contamination on the radiocarbon dating of the Dead Sea Scrolls I: castor oil. Radiocarbon 43(1):127-32.

Rasmussen KL, van der Plicht J, Doudna G, Cross FM, Strugnell J. 2003. Reply to Israel Carmi: "Are the ${ }^{14} \mathrm{C}$ dates of the Dead Sea Scrolls affected by castor oil contamination?" Radiocarbon 45(3):497-9.
Reimer PJ, Baillie MGL, Bard E, Bayliss A, Beck JW, Bertrand CJH, Blackwell PG, Buck CE, Burr GS, Cutler KB, Damon PE, Edwards RL, Fairbanks RG, Friedrich M, Guilderson TP, Hogg AG, Hughen KA, Kromer B, McCormac G, Manning S, Bronk Ramsey C, Reimer RW, Remmele S, Southon JR, Stuiver M, Talamo S, Taylor FW, van der Plicht J, Weyhenmeyer CE. 2004. IntCal04 terrestrial radiocarbon age calibration, 0-26 cal kyr BP. Radiocarbon 46(3):1029-58.

Sun M, Xu L, Saldana MDA, Temelli F. 2008. Comparison of canola meals obtained with conventional methods and supercritical $\mathrm{CO}_{2}$ with and without ethanol. Journal of the American Oil Chemistry Society 85: $667-75$.

Time magazine. 1957. "Out of the Desert” (n.a.), 15 April 1957 (American edition).

Ullmann B. 2007. Drying oils and related products. In: Ulrich B, editor. Ullmann's Encyclopaedia of Industrial Chemistry. 7th edition. DOI: 10.1002/ 14356007.a09_055.

van der Plicht J. 2004. Wincal25: the Groningen radiocarbon calibration program. http://www.rug.nl/cio.

van der Plicht J, Hogg A. 2006. A note on reporting radiocarbon. Quaternary Geochronology 1:237-40.

Vermes G. 1977. The Dead Sea Scrolls. Qumran in Perspective. Revised edition. Philadelphia: Fortress.

Wasson C. 2005. Women in the Damascus Document. Leiden: Brill.

Yardeni A. 1996. In: Baumgarten J, editor. Qumran Cave 4. XIII. The Damascus Document. Discoveries in the Judean Desert 18. Oxford: Clarendon Press. p 26-30.

Yardeni A. 1997. The Book of Hebrew Script. Jerusalem: Carta.

Yardeni A. 2007. A note on a Qumran scribe. In: Lubetski M, editor. New Seals and Inscriptions, Hebrew, Idumean and Cuneiform. Sheffield: Phoenix Press. p 287-98.

Young I. 2002. The stabilization of the biblical text in the light of Qumran and Masada: a challenge for conventional Qumran Chronology? Dead Sea Discoveries 9: 364-90.

Young I. 2005. The biblical scrolls from Qumran and the Masoretic text: a statistical approach. In: Dacy M, Dowling J, Faigan S, editors. Feasts and Fasts: A Festschrift in Honour of Alan David Crown. Mandelbaum Studies in Judaica 11. Sydney: Mandelbaum Publishing. p 81-139. 